\title{
Reciclado de escorias de fondo de central térmica para su uso como áridos en la elaboración de componentes prefabricados de hormigón
}

\section{Recycling power plant slag for use as aggregate in precast concrete components}

\author{
M. Orna Carmona ${ }^{(*)}$, J. González Paules(*), J. C. Sánchez Catalán(*), L. Fernández Pousa(*), \\ R. Ade Beltrán ${ }^{(*)}$, F. Quero Sanz(*)
}

Recepción/Received: 22-IV-09

Aceptación/Accepted: 9-XI-09

Publicado online/Online publishing: 17-XII-10

RESUMEN

La necesidad de eliminar residuos genera gastos. Considerando criterios de conservación ambiental, minimización del consumo de recursos naturales y ahorro de energía parece claro la necesidad y conveniencia de estudiar la viabilidad del uso de residuos. Sin embargo la utilización de residuos depende de que sean competitivos económicamente. Por tanto el propósito de esta investigación es evaluar el posible uso de las escorias de fondo de una central térmica como áridos para la fabricación de hormigón.

En este estudio se incluye la determinación de características físicas, químicas y térmicas y se han comparado los resultados a los requeridos por la EHE para determinar su aceptación o rechazo como componente de un hormigón. El objetivo final de la investigación responde a la utilización de hormigón con el máximo contenido en escorias sin modificar las condiciones de resistencia y durabilidad, consiguiendo un ahorro económico en la fabricación de estructuras prefabricadas.

Palabras clave: Cemento Portland, Escoria de fondo, Hormigón Prefabricado, Reacción álcali-árido, Trabajabilidad.

\section{SUMMARY}

The need to eliminate waste generates costs. When considering the preservation of the environment, the minimization of the consumption of natural resources and energy savings criteria, the need and advisability of studying the feasibility of waste re-use seems clear. However, waste re-use depends on whether they are economically competitive. Therefore, the aim of this study is to evaluate the possible use of slag from a steam power station as aggregate in the manufacture of concrete.

This study included the determination of the physical, chemical and thermal properties of the material, comparing the results to those required by the Spanish structural concrete code (EHE) in determining their acceptance or rejection as a concrete component. The ultimate aim of the research was to determine the highest slag content that could be added to concrete without modifying its strength or durability, with a view to obtaining savings in the manufacture of precast structures.

Keywords: Portland Cement, Slag, Precast Concrete, Alkali-Aggregate Reaction, Workability.

(*) (EUPLA). Universidad de Zaragoza (La Almunia de Doña Godina, España). 


\section{INTRODUCCIÓN}

El uso de residuos de la industria en la fabricación de materiales de construcción permite la reducción del impacto medioambiental generado así como el consiguiente ahorro energético y en el coste de las materias primas empleadas en el proceso constructivo.

Existen varios ejemplos de residuos incorporados de forma segura y razonable en los cementos y también a los materiales de construcción, de los que la microsílice, las cenizas volantes y las escorias suponen argumentos exitosos. Así, la microsílice se aplica a la fabricación de hormigones (1). Las cenizas pueden emplearse como sustitutivo de cemento $(2,3)$. Igualmente se han ensayado en la preparación de hormigones las escorias procedentes de altos hornos o derivadas de centrales térmicas de gasificación inducida por ciclo combinado (escorias GICC); las primeras se pueden usar en la formulación de cementos (4), mientras las segundas se han estudiado como componente en la fabricación de ladrillos (5), como árido en la dosificación de hormigón (6) y como materia prima para síntesis de materiales vitrocerámicos $(7,8)$.

No obstante, los estudios referentes a residuos de centrales térmicas convencionales hacen referencia, fundamentalmente, a las cenizas volantes puesto que han sido hasta ahora el material predominante, no hallando muchos datos bibliográficos relativos a las escorias de estas centrales.

El objeto de este trabajo es estudiar la viabilidad, desde el punto de vista técnico, del empleo de escorias procedentes de una central térmica tradicional y su aplicación como árido a la fabricación de hormigones, sin modificar las condiciones de resistencia y durabilidad de éstos, con objeto de su aplicación a la fabricación de estructuras prefabricadas. Ello puede conllevar el correspondiente ahorro en una empresa dedicada a esta actividad, donde el consumo de árido es notable, consiguiendo además una economía adicional en el transporte del mismo dada su cercana ubicación a la central termoeléctrica. Al mismo tiempo se consigue una disminución en el impacto medioambiental de la central, reciclando una parte importante de sus residuos.

La investigación llevada a cabo se ha desarrollado de acuerdo a la siguiente estructura:

- Caracterización físico-química de las escorias como árido de acuerdo a la norma EHE-08 y estudio de trazabilidad.

- Estudio de dosificación de hormigones y elección de la más adecuada.

- Verificación en piezas prefabricadas.

Se ha efectuado en colaboración con la empresa de prefabricados PAPHSA, ubicada en Alcañiz (Teruel) utilizando

\section{INTRODUCTION}

The use of industrial waste in the manufacture of construction materials reduces the environmental impact generated, with the concomitant savings in the cost of the energy and prime materials used in construction.

Silica fume, fly ash and slag are examples of waste that have been safely and reasonably included in cement and other building materials. Silica fume is used in concrete manufacture (1), while fly ash can be used to replace cement $(2,3)$. Blast furnace slag or slag from gas-fired combined cycle plants has also been tested in concrete manufacture, the former in cement (4) and the latter as a component in brick-making (5), an aggregate in concrete proportioning (6) and a prime material for vitroceramic material synthesis $(7,8)$.

That notwithstanding, studies on conventional steam plant waste refer primarily to fly ash, which has been the predominant material to date. Very few papers have been published, by contrast, on the slag from these plants.

The present study aimed to determine the technical feasibility of using conventional steam power plant slag as an aggregate in concrete for precast structures without affecting the strength or durability of the final product. This may entail savings for manufacturers engaging in this aggregate-intensive business, in terms not only of the prime material, but also of carriage costs, for these facilities can be sited near power plants. At the same time, by recycling a large proportion of the resulting waste, these arrangements reduce the environmental footprint attributed to electricity generation.

The research conducted focused on the following:

- Physical-chemical characterization of slag further to Spanish structural concrete code EHE- 08 and traceability studies.

- Concrete proportioning study and choice of the most appropriate mix proportions.

- Verification in precast slabs.

The study was conducted in conjunction with PAPHSA, a precasting company located at Alcañiz in the Spanish 
escorias procedentes de la central térmica de Andorra (Teruel) y ha sido financiada por el Ministerio de Ciencia e Innovación y por el Ministerio de Industria (programas PROFIT Y CDTI). Los ensayos se han efectuado en el Laboratorio de Materiales de la Escuela Universitaria Politécnica de La Almunia (Universidad de Zaragoza), habiendo contado con la colaboración de los Laboratorios para la Calidad del Gobierno de Aragón y el laboratorio privado Arcotecnos.

\section{CARACTERIZACIÓN DE LAS ESCORIAS}

\subsection{Origen y descripción}

Las escorias estudiadas corresponden a la central térmica de Andorra. Está situada en la provincia de Teruel y es propiedad de Endesa. Entró en funcionamiento en 1981 y tiene una potencia de $1.050 \mathrm{MW}$. Es una central termoeléctrica que utiliza tecnología convencional. El lignito empleado como combustible contiene alrededor de un $7 \%$ de azufre, estando equipada la central con filtros que eliminan un $90 \%$ por desulfuración húmeda del dióxido de azufre generado. province of Teruel, using slag from a steam power plant at Andorra in the same province, and funded by the Ministries of Science and Innovation (Programme for the Furtherance of Technological Research, PROFIT) and Industry CDTI (Centre for Technological Development in Industry). The tests were run at the Materials Laboratory in the University of Zaragoza's La Almunia Polytechnic College, the regional Government of Aragon's quality control laboratories and Arcotecnos, a private laboratory.

\section{SLAG CHARACTERIZATION}

\subsection{Origin and description}

The slag studied was provided by the 1050-MW Andorra power plant located in the Spanish province of Teruel, commissioned in 1981 and owned by Endesa, a Spanish energy utility. This conventional coal- fired plant is fitted with filters that remove $90 \%$ of the $7 \%$ sulphur in the coal by wet desulphurization of the sulphur dioxide generated.

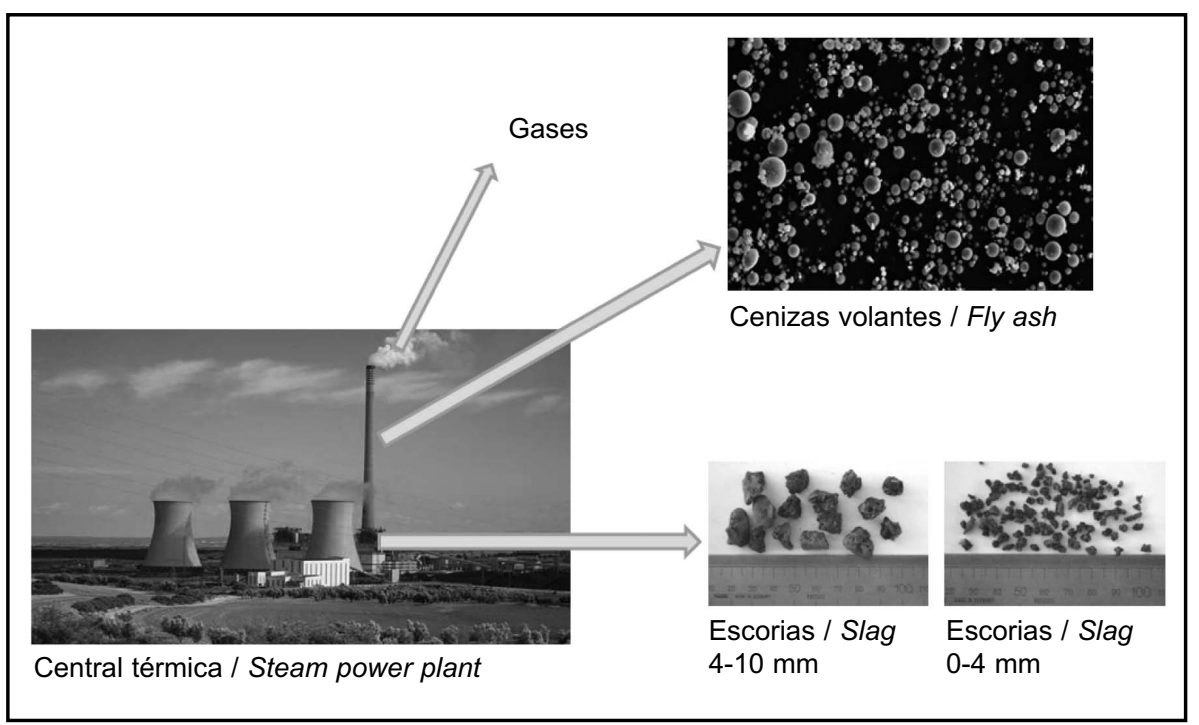

Figura 1. Principales residuos de central térmica convencional.

Figure 1. Main types of conventional power plant waste.

Las escorias objeto de estudio son de color negruzco y están clasificadas en dos fracciones granulométricas: 0-4 $\mathrm{mm}$ (árido fino) y 4-10 mm (árido grueso) (Figura 1).

Estas escorias ya se están usando por la empresa Matreco en piezas cerámicas prefabricadas, elaborándose bloques y ladrillos aligerados de diferentes tipos.

Para su estudio, las escorias se homogeneizan y cuartean hasta obtener la masa de ensayo especificada en cada uno de ellos.
The slag studied was blackish and classified into two particle size fractions: 0-4 (fine) and 4-10 (coarse) aggregate (Figure 1).

This slag is presently being used by Matreco, a claybased materials manufacturer, for several types of lightweight block and brick.

In the present study, it was homogenized and fractionated until the test mass specified in each case was obtained. 
Las dos muestras se someten a análisis de difracción de rayos $X$, obteniéndose los difractogramas representados en las Figuras 2 y 3 . La Tabla 1 muestra la composición química aproximada de las escorias. Aparecen tres fases principales: cuarzo, óxido de hierro y una fase de alumino-silicato, posiblemente mullita o albita.
$X$-ray diffraction methods were used to analyze the coarse and fine samples. The resulting diffractograms are shown in Figures 2 and 3. Table 1, in turn, gives the approximate chemical composition of the slag. The three main phases identified were quartz, iron oxide and an alumina- silicate phase, possibly mullite or albite.

Tabla 1 / Table 1

Resultados caracterización por difractograma de las escorias. $X R D$ findings for the slag characterized.

\begin{tabular}{|c|c|c|c|c|c|c|c|c|}
\hline & $\mathbf{S i O}_{2}$ & $\mathbf{A l}_{2} \mathbf{O}_{3}$ & $\mathrm{Fe}_{2} \mathbf{O}_{3}$ & $\mathrm{CaO}$ & $\mathbf{K}_{2} \mathbf{O}$ & $\mathbf{M g O}$ & $\mathbf{S O}_{3}$ & $\mathbf{N a}_{2} \mathbf{O}$ \\
\hline $0-4$ & 40.19 & 25.63 & 23.82 & 5.68 & 1.11 & 1.11 & 0.620 & 0.126 \\
\hline $4-10$ & 35.91 & 33.36 & 21.16 & 5.75 & 0.984 & 0.843 & 0.3775 & 0.094 \\
\hline
\end{tabular}

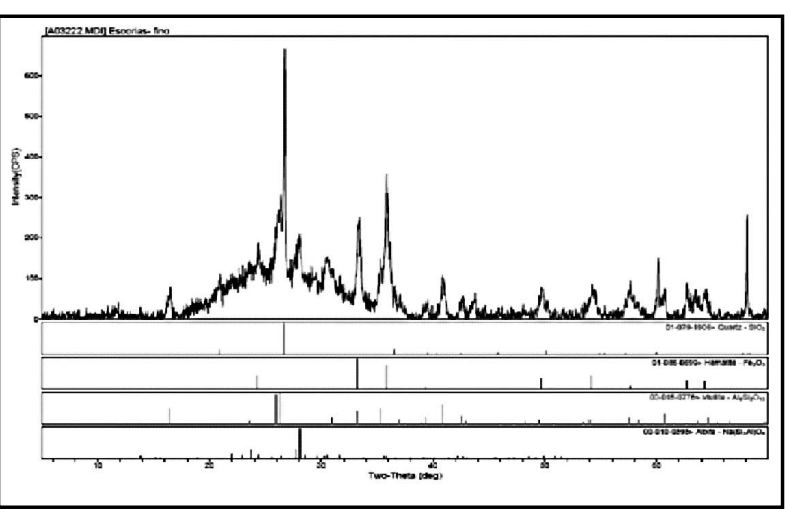

Figura 2. Escorias finas $0-4 \mathrm{~mm}$.

Figure 2. Fine slag, 0-4 mm.

\subsection{Caracterización de las escorias como áridos}

Se procede a la caracterización físico-química de las escorias como áridos. Para ello se llevan a cabo las correspondientes determinaciones físicas y químicas de acuerdo a las normas UNE.

Las determinaciones de óxido de hierro, óxido de calcio y óxido de magnesio se han efectuado mediante espectrofotometría de absorción atómica.

La reacción álcali-sílice se ha efectuado por el método químico.

La reacción álcali-carbonato se consigue a partir de los valores de calcio y magnesio obtenidos por la espectrofotometría de $A A$, mientras que aluminio se establece a partir de las medidas de dispersión de rayos $X$.

Se corroboran los resultados con el laboratorio privado Arcotecnos.

A continuación se expresan los resultados obtenidos en las diferentes determinaciones relativas a la caracterización de las escorias. La Figura 4 muestra la granulometría de las escorias empleadas.

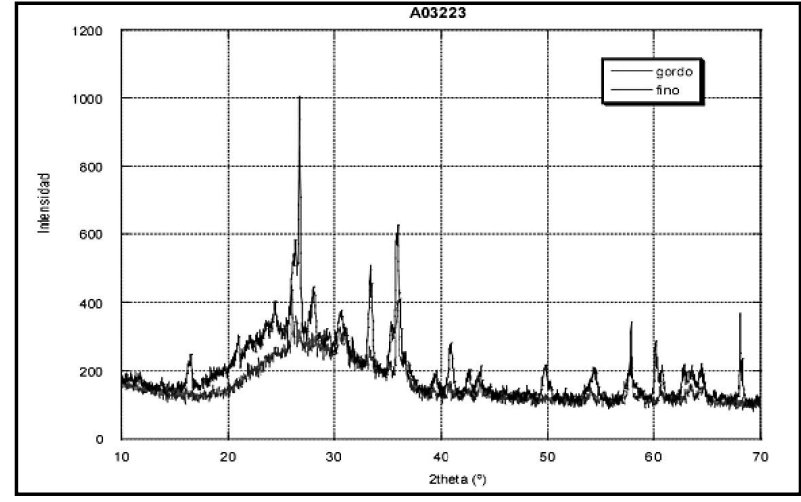

Figura 3. Escorias gruesas 4-10 mm. Figure 3. Coarse slag, $410 \mathrm{~mm}$

\subsection{Slag characterization for use as aggregate}

The aggregate was characterized physically and chemically as specified in the respective Spanish standards.

Iron, calcium and magnesium oxide contents were determined by atomic absorption spectrophotometry.

The material was tested for the alkali silica reaction using chemical methods.

The alkali-carbonate rock reaction was deduced from the calcium and magnesium values found with $A A$ spectrophotometry, while aluminium was identified on the grounds of the XRD measurements.

The findings were corroborated by the results of the tests conducted by Arcotecnos, a private laboratory.

The results of the aforementioned characterization procedures are set out below. Figure 4 shows the particle size distribution of the slag used. 


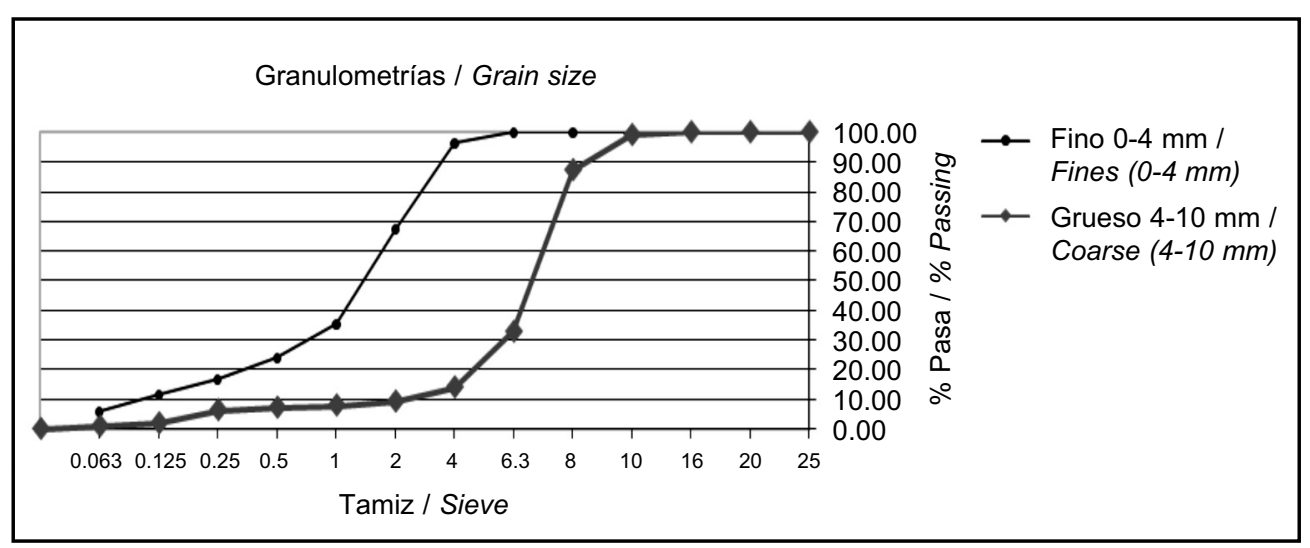

Figura 4. Granulometría de las escorias. Figure 4. Slag particle size distribution.

En la Tabla 2 se muestran los resultados obtenidos para los caracteres físicos y mecánicos, térmicos y de alteración y químicos (9).
The physical, mechanical, thermal and chemical properties found for the slag are summarized in Table 2, along with the alteration values (9).

Tabla 2 / Table 2

Resultados de caracterización de las escorias.

Results of slag characterization.

\begin{tabular}{|c|c|c|c|}
\hline $\begin{array}{l}\text { Valores máximos de sustancias perjudiciales y características requeridas por la EHE para áridos I } \\
\text { Maximum values of damaging substances and characteristics required for aggegates by EHE }\end{array}$ & $\begin{array}{l}\text { Máximo \% del } \\
\text { Peso de muestra / } \\
\text { Maximum \% of } \\
\text { Sample Weight }\end{array}$ & $\begin{array}{l}\text { Valores de } \\
\text { estudio I } \\
\text { Study Values }\end{array}$ & \\
\hline $\begin{array}{l}\text { Terrones de arcilla, determinados con arreglo al método de ensayo indicado en la UNE 7133:58 / } \\
\text { Clay clods, determined according to the trial method indicated in UNE2 7133:58 }\end{array}$ & 1.00 & 0 & • \\
\hline $\begin{array}{c}\text { Partículas blandas, determinadas con arreglo al método de ensayo indicado en la UNE 7134:58 / Soft } \\
\text { particles, determined according to the trial method indicates in UNE 7134:58 }\end{array}$ & - & 0 & • \\
\hline $\begin{array}{l}\text { Contenido de materia orgánica según UNE EN 1744-1:99 (según coloración en disolución patrón) / Organic } \\
\text { material Content according to UNE EN 1744-1:99 (According to colouration in dissolution standard) }\end{array}$ & - & $\begin{array}{l}\text { Cumple / } \\
\text { Complies }\end{array}$ & • \\
\hline $\begin{array}{l}\text { Compuestos totales de azufre expresados en } \mathrm{SO}_{3}=\text { y referidos al árido seco, determinados con arreglo al } \\
\text { método de ensayo indicado en la UNE EN 1744-1:99 / Sulphur total compounds expressed as } \mathrm{SO}_{3} \\
\text { referred to dry aggregate, determined in accordance with the trial method indicated in UNE EN 1744-1:99 }\end{array}$ & - & 0 & • \\
\hline $\begin{array}{l}\text { Sulfatos solubles en ácidos, expresados en } \mathrm{SO}_{3}=\text { y referidos al árido seco, determinados según el método } \\
\text { de ensayo indicado en la UNE EN 1744-1:99 / Soluble sulphates in aggregates, en } \mathrm{SO}_{3}=\text { and referred } \\
\text { to dry aggregate, determined in accordance to the trial method indicated in UNE EN 1744-1:99 }\end{array}$ & 0.80 & 0 & - \\
\hline $\begin{array}{c}\text { Cloruros expresados en } \mathrm{Cl}^{-} \text {y referidos al árido seco, determinados con arreglo al método de ensayo } \\
\text { indicado en la UNE EN 1744-1:99 / Chloride expressed as Cl- and referred to dry aggregate, } \\
\text { determined in accordance to the trial method indicated in UNE EN 1744-1:99 }\end{array}$ & 0.05 & 0 & • \\
\hline Equivalente de arena según UNE - EN 933-8 / Equivalent of Sand according to UNE - EN 933-8 & 75 & 88.8 & • \\
\hline Coeficiente de forma (UNE EN 933-4:00 ) / Shape Index (UNE EN 933-4:00) & $>0.20$ & 0.35 & $\bullet$ \\
\hline Densidad y absorción UNE EN 1097-6:01 / Density and absorption UNE EN 1097-6:01 & Sin $\lim . / / 5 \%$ & $0.97 / / 1.9$ & $\bullet$ \\
\hline Resistencia al desgaste de la grava (UNE EN 1097-2:99) / Gravel Wear Resistance (UNE EN 1097-2:99) & 40 & $37 \%$ & $\bullet$ \\
\hline Resistencia del árido a los ciclos de hielo y deshielo / Aggregate Resistance to frost and defrost cycle & 0 & 0 & $\bullet$ \\
\hline Ensayo de sulfato de magnesio UNE - EN 1367-2) / Magnesium Sulphate Trial UNE - EN 1367-2) & $18 \%$ & $2.1 \%$ & $\bullet$ \\
\hline
\end{tabular}

La caracterización de la escoria se desarrolló previendo una sustitución en el hormigón del 100\% del árido. También se realizaron estos ensayos a los áridos empleados por la empresa PAPHSA para la fabricación de sus hormigones prefabricados.
The slag was characterized assuming that $100 \%$ of the aggregate in the concrete would be replaced. These tests were also conducted on the aggregate used by PAPHSA to manufacture its precast concrete. 
Se observó que la escoria por si sola es reactiva tanto al álcali-sílice, álcali silicato y al álcali-carbonato. Una vez mezclada en el porcentaje definitivo $70 \%-30 \%$ se volvieron de realizar los ensayos obteniendo como resultados los indicados en las tablas y figuras siguientes.

La Tabla 3 y la Figura. 5 muestra los resultados obtenidos para las reactividades álcali-sílice, álcali-silicato de mezcla (70\% árido calizo-30\% escoria) según (UNE 146507-1:1999 EX).
When tested alone, the slag was observed to have a low resistance to the alkali silicon, alkali-silicate and alkalicarbonate rock reactions. The tests were re-run on the aggregate in the proportion ultimately used, namely 70 $30 \%$, with the results set out in the tables and figures below.

Table 3 and Figure 5 show the alkali-silicon and alkalisilicate reactivity for the aggregate mix (70\% limestone aggregate $30 \%$ slag), found as specified in UNE 1465071:1999 EX.

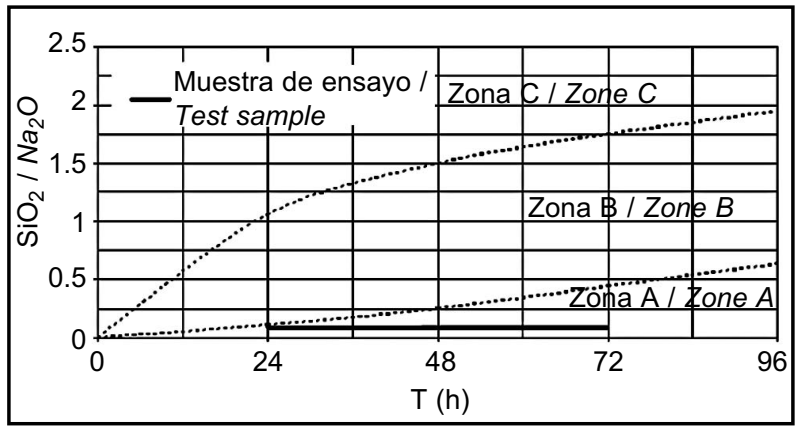

Figura 5. Reactividad álcali-sílice y álcali-silicato.

Figure 5. Alkali-silicon and alkali silicate reactivity.

Tabla 3 / Table 3

Reactividad álcali-sílice y álcali-silicato (70\% caliza-30\% escoria).

Alkali silicon and alkali silicate reactivity (70\% limestone 30\% slag).

\begin{tabular}{|c|c|c|c|}
\hline Valores medios sobre tres determinaciones / Average values on three determinations & $24 \mathrm{~h}$ & $48 \mathrm{~h}$ & $72 \mathrm{~h}$ \\
\hline Concentración de $\mathrm{Si}_{2} \mathrm{O}$ en el filtrado $(\mathrm{mmol} / \mathrm{l}) / \mathrm{Si}_{2} \mathrm{O}$ Concentration in the filtration $(\mathrm{mmol} / \mathrm{l})$ & 19.03 & 20.26 & 26.26 \\
\hline Concentración de $\mathrm{Nai}_{2} \mathrm{O}$ en el filtrado $(\mathrm{mmol} / \mathrm{l}) / \mathrm{Nai}{ }_{2} \mathrm{O}$ concentration in the filtration $(\mathrm{mmol} / \mathrm{l})$ & 248.47 & 206.52 & 261.38 \\
\hline Relación molar $\mathrm{Sii}_{2} \mathrm{O} / \mathrm{Nai}_{2} \mathrm{O} / \mathrm{Molar}$ ratio $\mathrm{Sii}_{2} \mathrm{O} / \mathrm{Nai}_{2} \mathrm{O}$ & 0.08 & 0.1 & 0.1 \\
\hline
\end{tabular}

La Tabla 4 y la Figura 6 muestran los resultados de la reactividad de la mezcla (70\% árido calizo-30\% escoria) según (UNE 146507-2:1999).
Table 4 and Figure 6 show the reactivity of the mix (70\% limestone aggregate - 30\% slag), found as specified in UNE 146507- 2:1999.

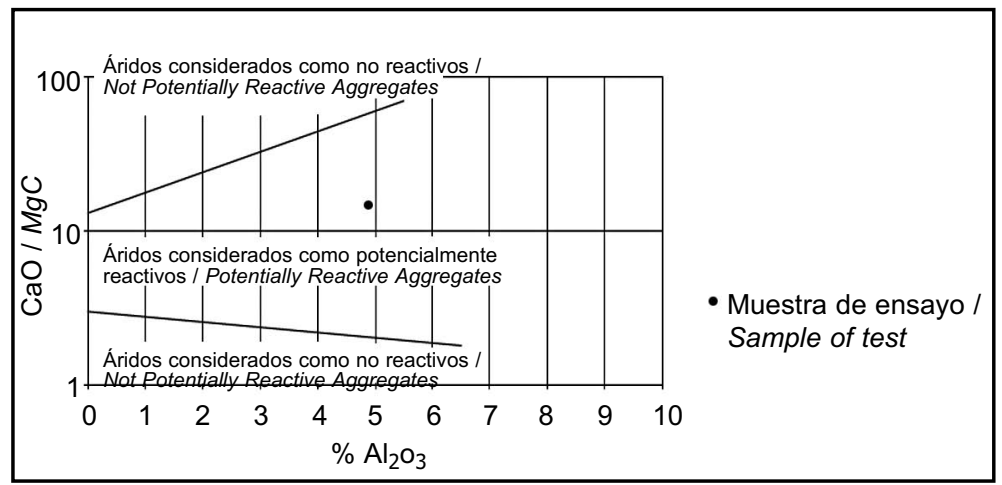

Figura 6. Reactividad álcali-carbonato.

Figure 6. Alkali carbonate reactivity.

Al ser el árido mezcla potencialmente reactivo al álcalicarbonato, se deben emplear cementos con bajos niveles de álcalis y respetar las especificaciones que hace la EHE, (9), respecto a la utilización de áridos potencialmente reactivos.
In light of the potentially low resistance of the mixed aggregate to the alkali- carbonate reaction, low alkali cement must be used and the structural concrete code (9) specifications for partially reactive aggregate must be observed. 
Tabla 4 / Table 4

Reactividad álcali-carbonato.

Alkali carbonate reactivity.

\begin{tabular}{|c|c|}
\hline $\mathrm{CaO}$ & $35.50 \%$ \\
\hline $\mathrm{MgO}$ & $2.43 \%$ \\
\hline $\mathrm{Al}_{2} \mathrm{O}_{3}$ & $4.90 \%$ \\
\hline $\mathrm{CaO} / \mathrm{MgO}$ & 14.59 \\
\hline
\end{tabular}

\section{HORMIGONES FABRICADOS CON LAS ESCORIAS}

Con objeto de estudiar la aportación de las escorias descritas a la fabricación de hormigones se diseña un programa experimental basado en dos actuaciones:

Ensayos de resistencia en probetas preparadas en distintos hormigones fabricados con estas escorias, en los que se pueda deducir la viabilidad de las mismas, desde el punto de vista técnico, como árido fino o como árido grueso. A partir de ahí, establecer la dosificación idónea, según el caso.

Verificación en piezas prefabricadas: atendiendo a los resultados obtenidos, preparación de una pieza prefabricada con un hormigón en el que se aplique la escoria adecuada con su dosificación óptima, efectuando ensayos de resistencia aplicados a la misma.

\subsection{Ensayos en hormigones y dosificación de escorias}

El hormigón estudiado se va a dedicar a la confección de estructuras prefabricadas. Por ello debe ser autocompactante para el relleno de los moldes y además, debe adquirir la resistencia suficiente de forma temprana para poder desmoldar lo antes posible.

Para determinar el comportamiento de las escorias se preparan diferentes tipos de hormigones, empleando recetas similares a las utilizadas en planta. Se ha utilizado cemento tipo CEM I 52,5 R de la fábrica de Cemex en Morata de Jalón (Zaragoza), al que se incorporan los áridos originales empleados en la elaboración de hormigón de prefabricados, áridos finos rodados y de machaqueo de granulometría $0-4 \mathrm{~mm}$ y árido grueso de machaqueo de fracción 4-10 mm. Estos áridos son sustituidos, en su totalidad o en parte, por las escorias de fracción granulométrica 0-4 ó 4-10, respectivamente, en la forma en que posteriormente se describe para cada tipo de hormigón.

A todos los hormigones se añaden dos tipos de aditivos, un acelerador de fraguado (Lubracell) y un superfluidificante (Glenium ACE 325), ambos de la marca comercial BASH.

\section{SLAG- BEARING CONCRETE}

An experimental programme based on the two approaches discussed below was designed to study slag behaviour in concrete.

Strength tests were conducted on specimens made with different concretes prepared with this slag to deduce the technical feasibility of their use as a fine or coarse aggregate. The ideal dosage, as appropriate, was then established.

Precast slabs were tested. On the grounds of the results, precast slabs were prepared with concrete containing the optimal proportion of slag for subsequent strength testing.

\subsection{Concrete testing and slag proportioning}

The concrete studied was intended for use in the precasting industry. Consequently, it had to be selfconsolidating to fill the moulds and acquire sufficient early age strength for prompt removal from these dies.

Different types of concretes were prepared to determine slag performance, batching the components in proportions similar to plant usage. CEM I 52.5 R cement supplied by Cemex, a company located at Morata de Jalón in the Spanish province of Zaragoza, was used to prepare the concrete, with conventional aggregate, namely 0-4 $\mathrm{mm}$ natural and crushed fines and 4-10 $\mathrm{mm}$ crushed coarse materials. This aggregate was replaced wholly or partially by $0-4$ or $4-10 \mathrm{~mm}$ slag in each concrete as described below.

All concretes bore an accelerating admixture (Lubracell) and a superplasticizer (Glenium ACE 325), both manufactured by BASH. 
Se emplea agua de la red de abastecimiento de La Almunia efectuando su análisis químico y microbiológico, que confirma su potabilidad y su aptitud para la fabricación de hormigones.

Los hormigones se preparan con una hormigonera de eje vertical de 100 litros de capacidad máxima. Las amasadas se llevaron a cabo añadiendo el cemento, los aditivos y los áridos correspondientes según el tipo de hormigón preparado e incorporando el agua de forma gradual hasta obtener una masa homogénea. Ninguno de los hormigones presentó un escurrimiento superior a $60 \mathrm{~cm}$ al realizar el cono de Abrams para determinar la consistencia.

De cada hormigón obtenido se preparan cinco probetas cilíndricas de $15 \mathrm{~cm}$ de diámetro por $30 \mathrm{~cm}$ de altura, procediendo a su rotura a las 24 horas, 48 horas y 28 días de acuerdo a la norma UNE EN 12390-3:2003 y curadas en cámara húmeda según norma UNE EN 12390-2:2001 (9).

\subsubsection{Trazabilidad de muestras y probetas}

Para garantizar la trazabilidad se configuró un sistema de designación de las probetas basado en la codificación del tipo de hormigón, el tamaño de la escoria, el número de probetas y la serie a la que pertenecían dichas probetas (Figura 7).
La Almunia tap water was analyzed chemically and microbiologically and found to be potable and consequently apt for concrete manufacture.

The concrete was prepared in a 100 I vertical shaft mixer, first adding the dry components (cement, admixtures and aggregate) and then gradually the water until a homogeneous mix was obtained. None of the concretes exhibited a slump of over $60 \mathrm{~cm}$ when tested for consistency.

Five $15 \mathrm{~cm}$ diameter, $30 \mathrm{~cm}$ high cylindrical specimens were prepared from each concrete. They were cured in a humidity chamber as per UNE EN 12390-2:2001 (9) for 24 or 48 hours or 28 days before testing to failure as specified in standard UNE EN 12390-3:2003.

\subsubsection{Sample and specimen traceability}

The specimens were coded for traceability with a system that identified the concrete manufacturer, slag size, and number of specimens and series, as shown in the diagram in Figure 7.

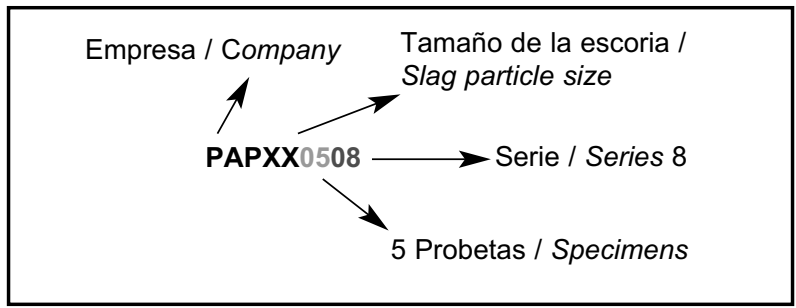

Figura 7. Designación de probetas.

Figure 7. Specimen coding.

En nuestro caso la empresa a la que se le realizaba el ensayo es PAP - PAPHSA.

Siendo el tamaño de la escoria designado por:

- NADA - Hormigón Patrón o de Referencia.

- E - Hormigón con escoria fina 0-4 mm.

- EG - Hormigón con escoria gruesa 4-10 mm.

\subsubsection{Aplicación de las escorias como sustitutivo del árido fino}

Se preparan cuatro tipos de hormigones en base a sustituir el $25 \%, 50 \%, 75 \%$ y $100 \%$ del árido fino convencional por escorias correspondientes a la fracción 0-4 mm.

Tomando las resistencias medias a 24 horas de cada lote de probetas se obtiene la curva de resistencias referida en la Figura 8.
The manufacturer in the present study was PAP PAPHSA.

The slag size was designated as:

- NO DATA - control or reference concrete.

- E concrete with 0-4 mm fine slag.

- EG concrete with 4-10 mm coarse slag.

\subsubsection{Replacement of fine aggregate with slag}

Four types of concrete were prepared, replacing 25, 50, 75 and $100 \%$ of the conventional fines with $0-4 \mathrm{~mm}$ slag.

The mean 24 hour strength for each series of specimens yielded the strength curve shown in Figure 8. 


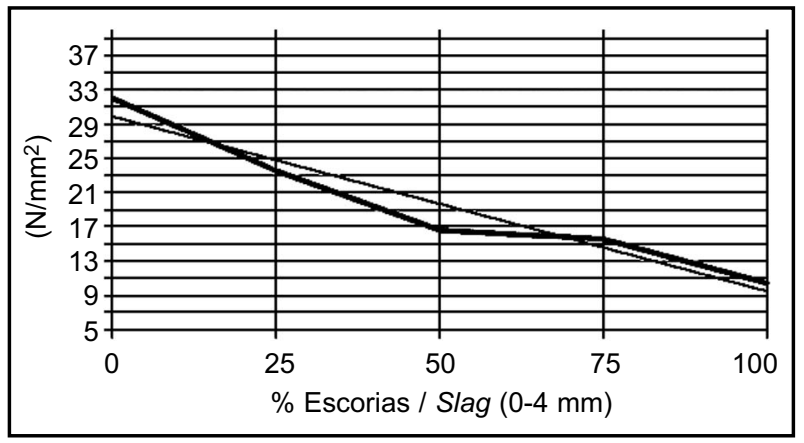

Figura 8. Curva de resistencias de hormigones preparados con escorias 0-4 $\mathrm{mm}$. Figure 8. Strength curve for concrete prepared with 0-4 $\mathrm{mm}$ slag.

\subsubsection{Aplicación de las escorias como sustitutivo del árido grueso}

De forma similar, se fabrican tres series de hormigones por sustitución del $25 \%$, 50\% y $75 \%$ del árido grueso convencional con escorias de la fracción granulométrica 4-10 mm.

No se prepara, como en el caso de las escorias finas, un hormigón con sustitución del $100 \%$ por prever una importante caída en la resistencia.

\subsubsection{Replacement of coarse aggregate with slag}

Similarly, three series of concretes were made in which 25,50 or $75 \%$ of the conventional coarse aggregate was replaced with 4-10 $\mathrm{mm}$ slag.

No concrete was prepared with a replacement ratio of $100 \%$ due to the significant decline in strength anticipated.

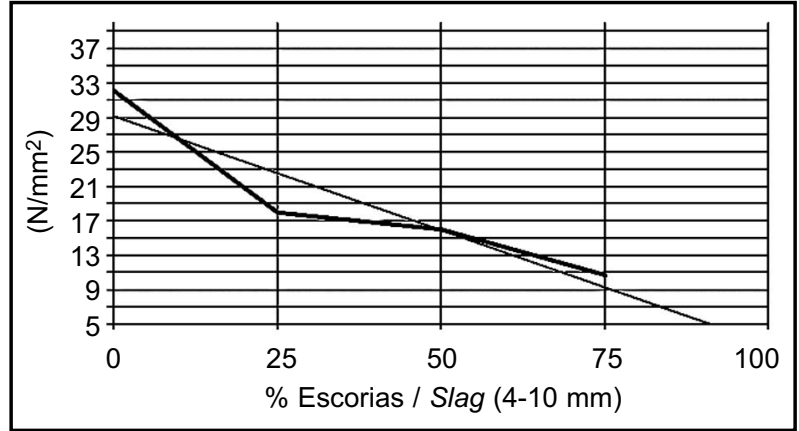

Figura 9. Curva de resistencias de hormigones preparados con escorias 4-10 mm. Figure 9. Strength curve for concrete prepared with $4-10 \mathrm{~mm}$ slag.

La curva de resistencias a 24 horas obtenida a partir de las resistencias medias se expresa en la Figura 9.

\subsubsection{Elección de la dosificación idónea}

A la vista de los resultados obtenidos en los hormigones anteriores se decide desechar el empleo de las escorias finas, por no interesar su rentabilidad económica en las cantidades a utilizar, aunque desde el punto de vista técnico queda confirmada su viabilidad.

Por ello, el estudio queda centrado en la utilización de la escoria gruesa pasando a determinar la dosificación más conveniente.

Se observa que cuanto mayor es la sustitución de árido por escorias más bajan las resistencias del hormigón. Se
The 24 hour mean strength curve found is shown in Figure 9.

\subsubsection{Choice of optimal dosage}

Although the results obtained for the above concretes showed that the use of fine slag was technically feasible, it was ruled out for reasons of cost- effectiveness.

The study consequently focused on coarse slag and the determination of its optimal proportion.

The findings showed that higher the replacement ratio, the greater was the decline in concrete strength. The 24 
decide que las resistencias necesarias para desmoldar a $24 \mathrm{~h}$ la sustitución del árido deben estar entorno al 30\%. Se fabrican tres nuevos hormigones por sustitución del árido grueso con escorias $4-10 \mathrm{~mm}$ del $25 \%$, 30\% y $35 \%$.

Los resultados obtenidos de resistencia de las probetas se muestran en las Tablas 5, 6 y 7 según un 25\%, 30\% y $35 \%$ de sustitución, respectivamente. hour strength required to remove the specimens from the moulds was established as the performance of specimens containing around $30 \%$ slag. Three new concretes were prepared, in which 4-10 mm slag accounted for 25, 30 or $35 \%$ of the total coarse aggregate.

The findings for 25,30 and $35 \%$ replacement ratios are given in Tables 5, 6 and 7, respectively.

Tabla 5 / Table 5

Dosificación y resistencias de probetas con $25 \%$ de árido grueso sustituido. Specimens with a $25 \%$ coarse aggregate replacement ratio.

\begin{tabular}{|c|c|c|c|c|c|c|c|}
\hline \multicolumn{2}{|l|}{ PAPEG0618 } & \multirow{2}{*}{$\begin{array}{l}N^{\circ} \text { Probetas I } \\
\text { Number of } \\
\text { test tubes } \\
6\end{array}$} & \multirow{2}{*}{\multicolumn{5}{|c|}{$\begin{array}{l}\text { Probetas con } 25 \% \text { de árido grueso sustituido por escorias I } \\
\text { Test tubes with } 25 \% \text { of coarse aggregate replaced by scoria }\end{array}$}} \\
\hline Fecha / Date & $18 / 11 / 2008$ & & & & & & \\
\hline Lubracell & & & \multicolumn{2}{|c|}{ Compactación / Compactation } & \multicolumn{2}{|c|}{ Mesa vibrante / Vibrating table } & \\
\hline Glenium & $0.202 \mathrm{Kg}$ & & \multicolumn{2}{|c|}{ Consistecia/Asiento / Consistency/Setting } & Seca / Dry & & \\
\hline $\begin{array}{l}\text { Relleno Betocarb / Filler } \\
\text { Betocarb }\end{array}$ & $0.954 \mathrm{Kg}$ & & \multicolumn{2}{|c|}{$\begin{array}{l}\text { D. previo a rotura / } \\
\text { Density prior to breaking }\end{array}$} & \multicolumn{3}{|c|}{$2.35 \mathrm{gr} / \mathrm{cm}^{3}$} \\
\hline Arena nat / Nat. sand & & & \multicolumn{2}{|c|}{ Trabajabilidad / Workability } & \multicolumn{3}{|c|}{ Buena / Good } \\
\hline Arena mezcla / Mixed Sand & $41.00 \mathrm{Kg}$ & & \multirow{2}{*}{\multicolumn{2}{|c|}{ 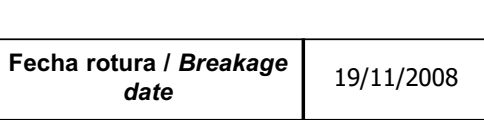 }} & & & \\
\hline Escorias 0-4 / Scoria 0-4 & & & & & PAPEG0118 & PAPEG0218 & \\
\hline Grava 4-12 / Gravel 4-12 & $15.48 \mathrm{Kg}$ & & \multicolumn{2}{|c|}{ Fuerza máxima / Maximum force } & $479.3 \mathrm{Kn}$ & $445.3 \mathrm{Kn}$ & $24 \mathrm{H}$ \\
\hline Escorias 4-10 / Scoria 4-10 & $5.16 \mathrm{Kg}$ & & \multicolumn{2}{|c|}{$\begin{array}{l}\text { Resistencia máxima / Maximum } \\
\text { resistance }\end{array}$} & $27.1 \mathrm{~N} / \mathrm{mm}^{2}$ & $25.2 \mathrm{~N} / \mathrm{mm}^{2}$ & \\
\hline Cemento / Cement & $9.54 \mathrm{Kg}$ & & $\begin{array}{c}\text { Fecha rotura / Breakage } \\
\text { Date }\end{array}$ & $16 / 12 / 2008$ & PAPEG0318 & PAPEG0418 & \\
\hline Agua / Water & $5.25 \mathrm{Kg}$ & & \multicolumn{2}{|c|}{ Fuerza máxima / Maximum force } & $860.8 \mathrm{Kn}$ & $619.8 \mathrm{Kn}$ & $28 \mathrm{D}$ \\
\hline Relación A/C / Relation A/C & 0.55 & & \multicolumn{2}{|c|}{$\begin{array}{l}\text { Resistencia máxima / Maximum } \\
\text { resistance }\end{array}$} & $48.7 \mathrm{~N} / \mathrm{mm}^{2}$ & $35.1 \mathrm{~N} / \mathrm{mm}^{2}$ & \\
\hline
\end{tabular}

Tabla 6 / Table 6

Dosificación y resistencias de probetas con $30 \%$ de árido grueso sustituido. Proportion and resistance of the test specimens with 30\% coarse aggregate replaced.

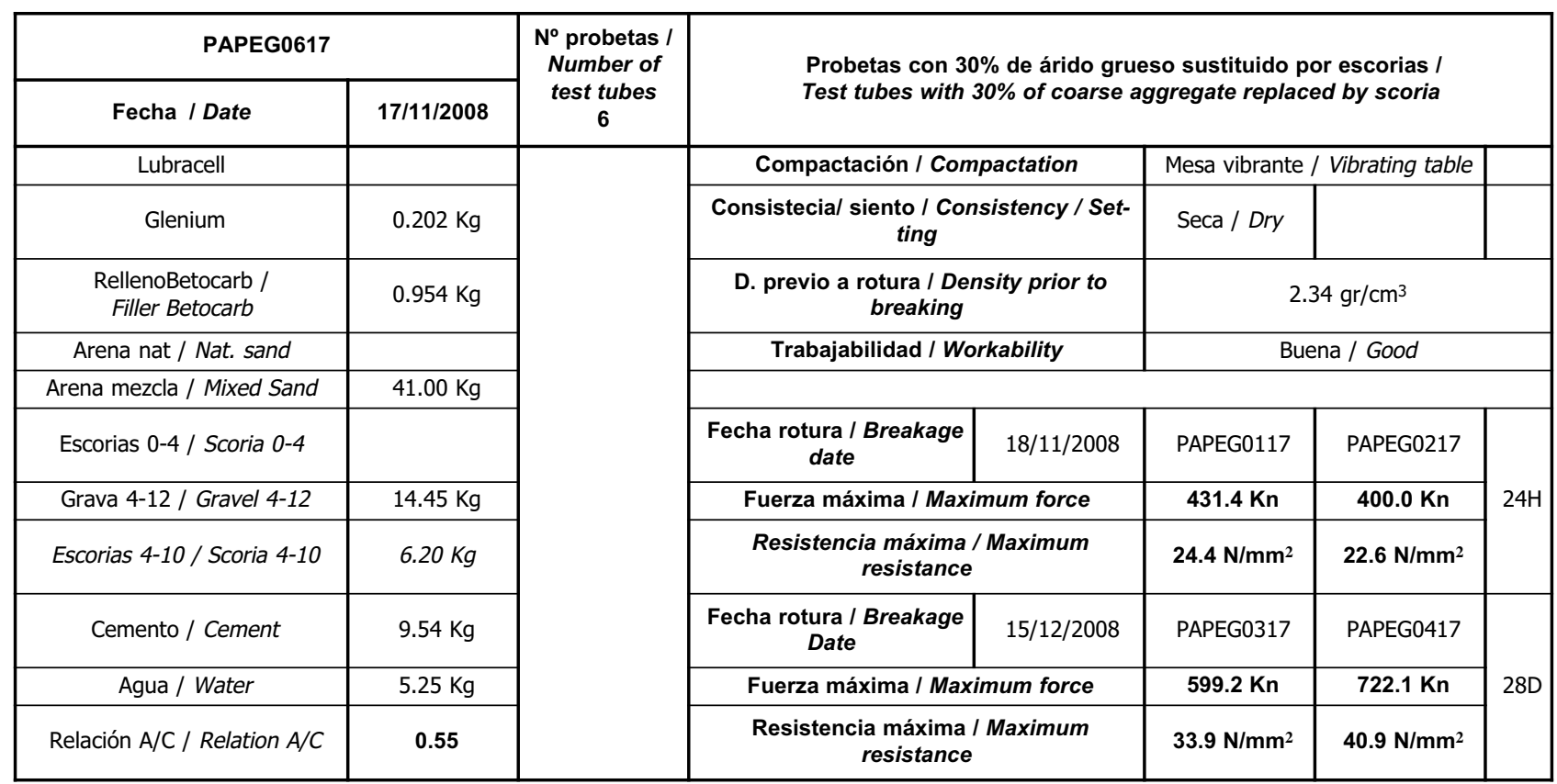


Tabla 7 / Table 7

Dosificación y resistencias de probetas con $35 \%$ de árido grueso sustituido.

Proportion and resistance of the test specimens with 35\% coarse aggregate replaced.

\begin{tabular}{|c|c|c|c|c|c|c|c|}
\hline \multicolumn{2}{|l|}{ PAPEG0616 } & \multirow{2}{*}{$\begin{array}{c}N^{\circ} \text { probetas I } \\
\text { Number of } \\
\text { test tubes } \\
6\end{array}$} & \multirow{2}{*}{\multicolumn{5}{|c|}{$\begin{array}{l}\text { Probetas con } 30 \% \text { de árido grueso sustituido por escorias I } \\
\text { Test tubes with } 30 \% \text { of coarse aggregate replaced by slag }\end{array}$}} \\
\hline Fecha / Date & $16 / 11 / 2008$ & & & & & & \\
\hline Lubracell & & & \multirow{2}{*}{\multicolumn{2}{|c|}{$\begin{array}{c}\text { Compactación / Compactation } \\
\text { Consistecia / Asiento / } \\
\text { Consistency / Setting }\end{array}$}} & \multicolumn{2}{|c|}{ Mesa vibrante / Vibrating table } & \\
\hline Glenium & $0.202 \mathrm{Kg}$ & & & & Seca / Dry & & \\
\hline Filler Betocarb / Filler Betocarb & $0.954 \mathrm{Kg}$ & & \multicolumn{2}{|c|}{$\begin{array}{l}\text { D. previo a rotura / } \\
\text { Density prior to breaking }\end{array}$} & \multicolumn{3}{|c|}{$2.34 \mathrm{gr} / \mathrm{cm}^{3}$} \\
\hline Arena nat / Nat. sand & & & \multicolumn{2}{|c|}{ Trabajabilidad / Workability } & \multicolumn{3}{|c|}{ Buena / Good } \\
\hline Arena mezcla / Mixed Sand & $41.00 \mathrm{Kg}$ & & & & & & \\
\hline Escorias 0-4 / Scoria 0-4 & & & $\begin{array}{l}\text { Fecha rotura I } \\
\text { Breakage date }\end{array}$ & $14 / 11 / 2008$ & PAPEG0116 & PAPEG0216 & \multirow{3}{*}{$24 \mathrm{H}$} \\
\hline Grava 4-12 / Gravel 4-12 & $13.42 \mathrm{Kg}$ & & \multicolumn{2}{|c|}{ Fuerza máxima / Maximum force } & $578.0 \mathrm{Kn}$ & $446.7 \mathrm{Kn}$ & \\
\hline Escorias 4-10 / Scoria 4-10 & $7.23 \mathrm{Kg}$ & & \multicolumn{2}{|c|}{$\begin{array}{l}\text { Resistencia máxima I } \\
\text { Maximum resistance }\end{array}$} & $33.7 \mathrm{~N} / \mathrm{mm}^{2}$ & $25.3 \mathrm{~N} / \mathrm{mm}^{2}$ & \\
\hline Cemento / Cement & $9.54 \mathrm{Kg}$ & & $\begin{array}{l}\text { Fecha rotura I } \\
\text { Breakage Date }\end{array}$ & $11 / 12 / 2008$ & PAPEG0316 & PAPEG0416 & \\
\hline Agua / Water & $5.25 \mathrm{Kg}$ & & \multicolumn{2}{|c|}{ Fuerza máxima / Maximum force } & $911.9 \mathrm{Kn}$ & $867.0 \mathrm{Kn}$ & $28 \mathrm{D}$ \\
\hline Relación A/C / Relation A/C & 0.55 & & \multicolumn{2}{|c|}{$\begin{array}{l}\text { Resistencia máxima / } \\
\text { Maximum resistance }\end{array}$} & $51.6 \mathrm{~N} / \mathrm{mm}^{2}$ & $49.1 \mathrm{~N} / \mathrm{mm}^{2}$ & \\
\hline
\end{tabular}

Se realizó también de las mismas amasadas probetas para la comprobación de permeabilidad del hormigón para garantizar la durabilidad del mismo y de las armaduras que podrían estar embebidas en él. Los resultados obtenidos se reflejan en la Tabla 8 .
Further specimens were prepared from the same batches of concrete to test permeability as a measure of the durability of concrete and embedded reinforcement bars. The findings are summarized in Table 8.

Tabla 8 / Table 8

Resultados de permeabilidad.

Permeability Results.

\begin{tabular}{|c|c|c|c|}
\hline Fecha / Date & 13/11/2008 & \multicolumn{2}{|c|}{ PAPEG0616 } \\
\hline \multicolumn{2}{|c|}{ Permeabilidad (mm) / Permeability (mm) } & PAPEG05/16 & PAPEG06/16 \\
\hline \multicolumn{2}{|c|}{ Penetración media / Average Penetration } & $18.9 \mathrm{~mm}$ & $16.6 \mathrm{~mm}$ \\
\hline \multicolumn{2}{|c|}{ Penetración máxima / Maximum Penetration } & $25.4 \mathrm{~mm}$ & $20.6 \mathrm{~mm}$ \\
\hline Fecha / Date & $17 / 11 / 2008$ & \multicolumn{2}{|c|}{ PAPEG0617 } \\
\hline \multicolumn{2}{|c|}{ Permeabilidad $(\mathrm{mm}) /$ Permeability $(\mathrm{mm})$} & PAPEG05/17 & PAPEG06/17 \\
\hline \multicolumn{2}{|c|}{ Penetración media / Average Penetration } & $12.1 \mathrm{~mm}$ & $15.9 \mathrm{~mm}$ \\
\hline \multicolumn{2}{|c|}{ Penetración máxima / Maximum Penetration } & $18.5 \mathrm{~mm}$ & $24.4 \mathrm{~mm}$ \\
\hline Fecha / Date & $18 / 11 / 2008$ & \multicolumn{2}{|c|}{ PAPEG0618 } \\
\hline \multicolumn{2}{|c|}{ Permeabilidad (mm) / Permeability $(\mathrm{mm})$} & PAPEG05/18 & PAPEG06/18 \\
\hline \multicolumn{2}{|c|}{ Penetración media / Average Penetration } & $12.8 \mathrm{~mm}$ & $12.6 \mathrm{~mm}$ \\
\hline \multicolumn{2}{|c|}{ Penetración máxima / Maximum Penetration } & $20.0 \mathrm{~mm}$ & $20.5 \mathrm{~mm}$ \\
\hline
\end{tabular}

\subsection{Ensayos en piezas prefabricadas}

Para completar el estudio se decide aplicar los resultados obtenidos a una prelosa, pieza prefabricada de hormigón armado, con el porcentaje de sustitución del 30\% de escoria. La elección está motivada por tener datos previos de resistencia de este componente sin ninguna sustitución de árido, y así poder contrastar los datos obtenidos con la pieza con mezcla.

\subsection{Tests on precast slabs}

The study was completed by applying the results obtained to a precast slab made with reinforced concrete containing $30 \%$ slag. This type of member was chosen because strength data were available for slabs with no aggregate replacement that could be compared to the values found in the experimental members. 


\subsubsection{Modelos de análisis}

Para que el estudio fuera más completo se desarrollo un modelo mediante M.E.F.

También se instrumentarón con bandas extensométricas la preslosas fabricadas para comprobar in situ la tensiones y desplazamientos tanto en el hormigón como en las armaduras (Figuras 10, 11 y 12).

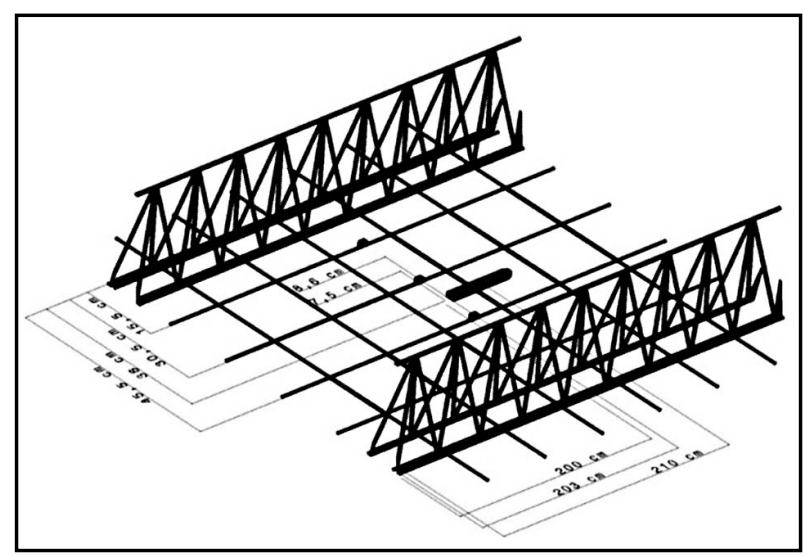

Figura. 10 Colocación sensores. CAD. Figure. 10 Sensor positions. CAD

Una vez instrumentadas se procedió a realizar el ensayo de flexión en una prensa de cuello de cisne.

\subsubsection{Resultados obtenidos}

Se obtuvieron los siguientes resultados:

\subsubsection{Analytical models}

A finite element analysis model was developed for this stage of the study.

The precast slabs were also instrumented with strain gauges for the on site monitoring of concrete and reinforcement stress and displacement. (Figures 10, 11 and 12)

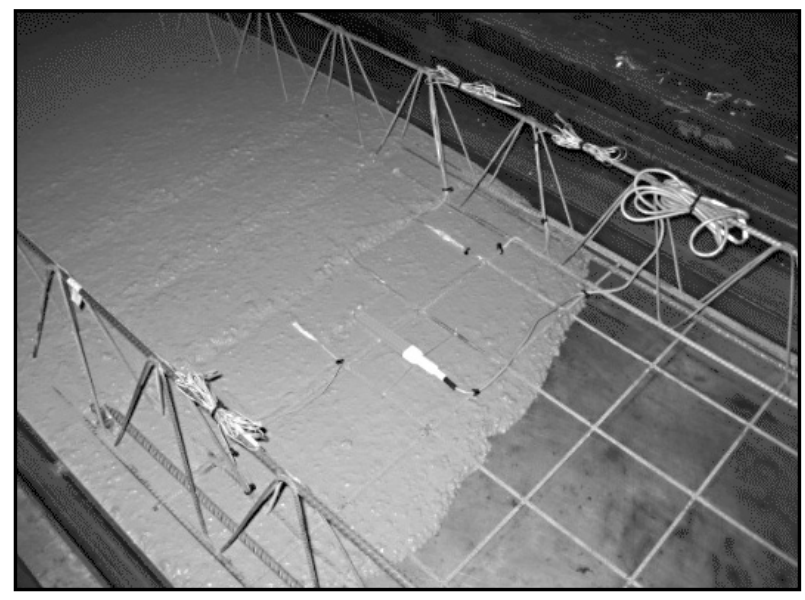

Figura. 11. Sensores embebidos. Figure. 11 Embedded sensors.

The instrumented slabs were also tested for bending strength on a testing machine.

\subsubsection{Results}

The results of these trials are discussed below.

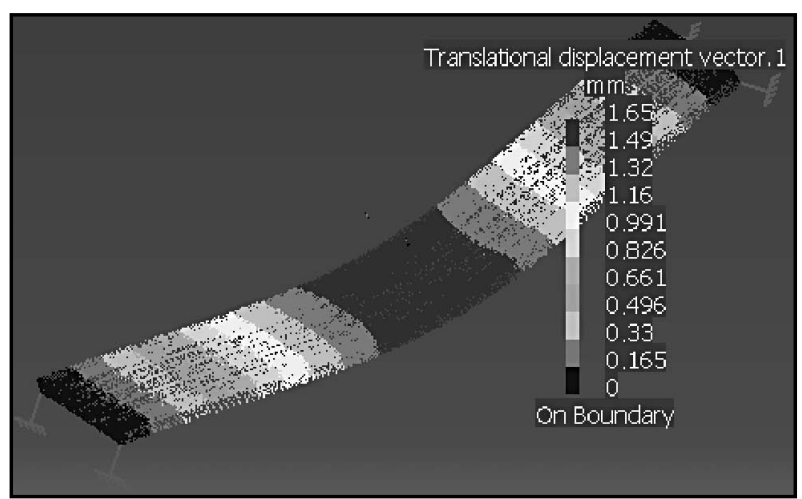

Figura 12. Resultados DOF de M.E.F.

Figure 12. Finite element model degrees of freedom (DOF).

La gráfica de los resultados obtenidos en las distintas prelosas ensayadas se muestran en la Figura 13.
The stress-strain diagrams for the precast slabs tested are shown in Figure 13. 


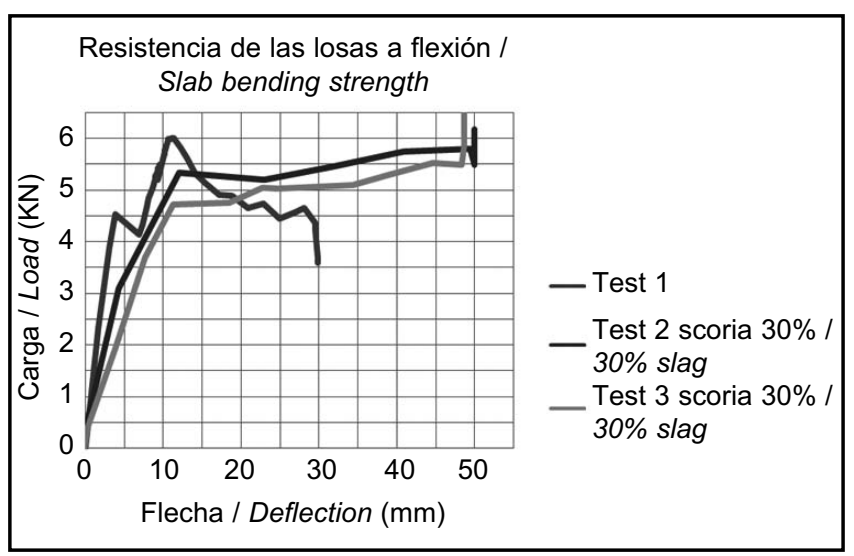

Figura. 13. Comparación de resistencia en las losas.

Figure. 13. Comparison of slab strength.

\section{CONCLUSIONES}

Se procede al estudio de la utilización de escorias de la central térmica convencional de Andorra (Teruel) a la elaboración de hormigón para prefabricados.

Los ensayos físicos, térmicos y químicos realizados en las escorias resultan satisfactorios para su empleo como árido, según la normativa EHE-08, salvo en la reacción álcali-carbonato, donde el árido es potencialmente reactivo como se ha indicado en la Figura 9. Este hecho condiciona la fabricación de hormigones según especifica la propia EHE en su artículo 37.3.8 "Resistencia frente a la reactividad álcali-árido", en la cual se indican las medidas a adoptar para evitar los fenómenos previsibles de expansión (9).

- Hormigones utilizados en ambientes no húmedos (clase general de exposición I y IIb).

- Empleo de cementos con un contenido de alcalinos, expresados como óxido de sodio equivalente $(0,658$ $\mathrm{K}_{2} \mathrm{O}+\mathrm{Na}_{2} \mathrm{O}$ ) inferior al $0,60 \%$ del peso del cemento.

También se podría considerar la utilización de los siguientes cementos para la fabricación de hormigón, con escorias como árido tras el estudio experimental pertinente de expansión del hormigón según UNE 146509 EX (9).

- Empleo de cementos comunes con adiciones (D, P, V) según UNE 197-1.

- Empleo de adiciones al hormigón (D ó V).

Se ha comprobado la resistencia conseguida por los hormigones, tanto para determinados rangos de sustitución del árido fino como del grueso, determinándose en ambos casos resistencias aceptables, siempre considerando que la limitación que nos marcábamos era la resistencia del hormigón a $24 \mathrm{~h}$ debido al proceso de desmolde que llevan las piezas prefabricadas.

\section{CONCLUSIONS}

The study analyzed the use in precast concrete manufacture of slag from the Andorra conventional steam power plant located the Spanish province of Teruel.

The physical, thermal and chemical tests conducted on the slag proved it to be apt for use as an aggregate, further to Spanish structural concrete code EHE-08, except as respects the alkali carbonate rock reaction, in which regard the material was observed to be potentially reactive (see Figure 9). This conditions concrete manufacture as specified in the aforementioned code, whose article 37.3.8 "Resistance to the alkali-aggregate reaction" lists the measures to be adopted to prevent foreseeable expansion (9).

- Concretes are to be used in non-humid environments (general exposure classes I and IIb).

- The cement used must have an alkaline content, expressed in equivalent sodium oxide $(0.658$ $\mathrm{K}_{2} \mathrm{O}+\mathrm{Na}_{2} \mathrm{O}$ ), lower than $0.60 \%$ by cement weight.

According to the findings of the experimental study on concrete expansion conducted as per UNE 146509 EX (9), concrete containing slag as an aggregate could also be manufactured under the following conditions:

- if common cement is duly additioned (with silica fume, pozzolans or fly ash) as per UNE 197-1;

- if concrete containing (silica fume or fly ash) admixtures is used.

Concrete strength was found for certain replacement ratios for both the fine and the coarse aggregate. In both cases 24 hour strength (the value relevant to precast concrete, due to the need to remove the material from the moulds) was observed to be acceptable. 
Se elige como dosificación idónea sobre la elaboración habitual de planta la de sustitución del árido grueso por un $30 \%$ de escorias de la fracción $4-10 \mathrm{~mm}$, por ser la idónea respecto a las resistencias obtenidas y sobre la cual también se realiza el ensayo de permeabilidad para comprobar la durabilidad del hormigón y obteniéndose valores aceptables.

Se confirma que el comportamiento del hormigón en piezas prefabricadas con la dosificación citada presenta características satisfactorias a esfuerzos de flexión. Consiguiendo resistencias similares a los hormigones sin sustitución de áridos con el consiguiente beneficio del reciclado de las escorias del proceso industrial.

Para conseguir un reciclado todavía mayor faltaría por comprobar la sustitución parcial de árido fino y árido grueso en la fabricación del hormigón y su comportamiento.

También se está trabajando en otro tipo de aplicaciones de la escoria como árido, por las propiedades que ésta posee.

\section{AGRADECIMIENTOS}

Los autores agradecen la confianza recibida por la empresa de prefabricados PAPHSA, perteneciente al grupo Alcance, ubicada en la localidad de Alcañiz (Teruel).

Asimismo agradecen la inestimable colaboración prestada por los laboratorios:

- Calidad de la Edificación y de Carreteras del Gobierno de Aragón.

- Laboratorio del Instituto de Ciencia de los Materiales (ICMA) de la Universidad de Zaragoza.

- Laboratorio Arcotecnos de Zaragoza, cuya amistad nos une a su director técnico, D. Enrique de la Rosa Ledesma.

Los materiales para desarrollar esta investigación han sido suministrados desinteresadamente por:

- Matreco suminstrando las escorias de fondo que provienen de la Central Térmica de Andorra (Teruel) propiedad de Endesa.

- Fábrica de cementos Cemex, de Morata de Jalón (Zaragoza) suministrando el cemento.

Finalmente, agradecemos la ayuda recibida a través del proyecto DESARROLLO TECNOLÓGICO DE NUEVOS PANELES EN CONTINUO DE HORMIGÓN BIOCLIMÁTICOS EN BASE A LA REUTILIZACIÓN DE ESCORIAS DE TÉRMICA Y RESIDUOS DE CONSTRUCCIÓN, dentro del programa CDTI del Ministerio de Industria.
Further to the strength test results, the optimal replacement ratio was $30 \%$ of the coarse aggregate. Concrete bearing 30\% 4-10 mm slag was also tested for permeability as a measure of its durability, with acceptable results.

Concrete manufactured with the above mix of coarse aggregate was also confirmed to exhibit satisfactory bending strength, with values similar to the findings for concrete containing $100 \%$ conventional aggregate, but with the additional benefit derived from the re- use of industrial waste.

The possibility of partially replacing both fine and coarse aggregate to attain higher recycling percentages while ensuring concrete performance has yet to be verified.

Work is also underway on other uses of slag as an aggregate, on the basis of its confirmed properties.

\section{ACKNOWLEDGEMENTS}

The authors appreciate the confidence placed in them by PHAPSA, an Alcance Group precasting company sited in Alcañiz in the Spanish province of Teruel.

Thanks are also due for the invaluable collaboration provided by the following laboratories:

- Construction and Roads Quality of the Regional Government of Aragon.

- Materials and Science Institute of the University of Zaragoza.

- Arcotecnos at Zaragoza, and in particular its technical manager, Enrique de la Rosa Ledesma.

The materials used in this research have been selflessly supplied by:

- Matreco, supplier of slag from the steam power plant in Andorra, sited in the Spanish province of Teruel and owned by Endesa.

- Cemex, supplier of cement from their factory in Morata de Jalón in Zaragoza.

Lastly, we are grateful for the funding received through the Project TECHNOLOGICAL DEVELOPMENT OF NEW CONTINUOUS CONCRETE BIOCLIMATIC PANELS BASED ON THE RE-USE OF STEAM POWER PLANT SLAG AND CONSTRUCTION WASTE, which forms part of the programme of the Centre for Technological Development in Industry of the Ministry of Industry. 


\section{BIBLIOGRAFÍA / BIBLIOGRAPHY}

(1) Aguado, A.; Gettu, R.; Agulló, L.: "La microsílice en el hormigón: una adición de altas prestaciones", Cemento hormigón, 890 (2006), pp. 56-66.

(2) Molina Bas, O.: "La influencia de las cenizas volantes como sustituto parcial del cemento Portland en la durabilidad del hormigón", Tesis Doctoral, E.T.S. de Ingenieros de Caminos, Canales y Puertos, Universidad Politécnica de Madrid, 2008.

(3) Rodríguez Santiago, J.: "El empleo de cenizas volantes en la fabricación de hormigones", Revista de Obras Públicas, 7 (1988), pp. 663-676.

(4) Moanta, A.; Paceagiu, J.; Andreescu, E.; Amzicá, F.: "Escoria de alto horno: una materia prima alternativa utilizada en el proceso de fabricación del clínker Pórtland"I, Cemento hormigón, 890 (2006), pp.16-22.

(5) Acosta, A.; Iglesias, I.; Aineto, M.; Romero, M.; y Rincón, J. M.: "Producción de ladrillos de pasta blanda (por prensado) a partir de escorias de central térmica GICC: Beneficios medioambientales", Tile \& Brick Int. 18 (2002), pp. 8-13.

(6) Ruiz, G.; Iglesias, I. y Acosta, A.: "Comportamiento en fractura de hormigones con escorias GICC", Anales de mecánica de la fractura, 22 (2005), pp. 571-574.

(7) Aineto, M.; Acosta, A.: "Las escorias de la central térmica GICC ELCOGAS como materia prima para la síntesis de materiales vitrocerámicos. Parte 1: Comportamiento en fusión de las escorias GICC y obtención del vidrio original", Bol. Soc. Esp. Ceram., V. 44 (2005) pp. 399-404.

(8) Aineto, M.; Acosta, A.; Rincón, J. M. y Romero, M.: "Las escorias de la central térmica GICC ELCOGAS como materia prima para la síntesis de materiales vitrocerámicos. Parte 2: Síntesis y caracterización de los materiales vitrocerámicos", Bol. Soc. Esp. Ceram., V. 45, (2006), pp. 28-32.

(9) "Instrucción de hormigón estructural (EHE-08)", BOE 22/08/2008, Spto. no 203, Ministerio de Presidencia (2008), pp. 96-106, 113, 156. 